\title{
Synthesis of Calcium Phosphate Extracted from Eggshell Waste through Precipitation Method
}

\author{
Aisyah Razak $^{1(D)}$, Najah Mat Isa ${ }^{1(D)}$, Sharifah Adzila ${ }^{1, * \text { (D }}$ \\ 1 Faculty of Mechanical \& Manufacturing Engineering, Universiti Tun Hussein Onn Malaysia (UTHM), Parit Raja, 86400, \\ Malaysia \\ * Correspondence: adzila@uthm.edu.my (S.A.);
}

Scopus Author ID 43760889800

Received: 8.03.2021; Revised: 4.04.2021; Accepted: 6.04.2021; Published: 9.04.2021

\begin{abstract}
Biomaterials for bone engineering applications are eagerly developing as traditional bone grafting methods show several drawbacks after and during operation. Eggshell waste contains high calcium suitable for developing biomaterials in hard tissue engineering as bone made up of calcium and phosphate. The precipitation method is one of the synthesis methods to produce calcium phosphate $(\mathrm{CaP})$. In this work, calcium source was extracted from eggshell waste while phosphate source was from ortho-phosphoric acid. The synthesized CaP powder was calcined at different temperatures. X-ray diffraction (XRD) analysis shows two types of CaP patterns are hydroxyapatite (HA) and $\beta$-Tricalcium phosphate ( $\beta$-TCP). Fourier transform infrared (FTIR) shows phosphate ion band in every sample while scanning electron microscopy (SEM) shows the transformation of structure from needle-like to more fluffy and rounded-edge structure from uncalcined to $1000^{\circ} \mathrm{C}$. From the results obtained, $\mathrm{CaP}$ extracted from eggshell waste was successfully synthesized from the precipitation method. This method contributes to the materials processing cost reduction and increases the application of natural materials instead of synthetic ones.
\end{abstract}

Keywords: Biomaterials; eggshell waste; calcium phosphate; hydroxyapatite

(C) 2021 by the authors. This article is an open-access article distributed under the terms and conditions of the Creative Commons Attribution (CC BY) license (https://creativecommons.org/licenses/by/4.0/).

\section{Introduction}

Bone is a dynamic and highly vascularized tissue that exhibits the unique capacity to remodel and heal without leaving scars. It provides structural support for the body and acts as a mineral reservoir as well [1,2]. Besides, the bone is living tissue that is the hardest among other connective tissues in the body [3]. Bone comprises 50 to $70 \%$ mineral, 20 to $40 \%$ organic matrix, 5 to $10 \%$ water, and <3\% lipids [4-6]. But, it does not mean bone cannot be injured or affected by diseases. Once a fracture or disease occurs on bone, bone grafting becomes the option of regenerating the bone. Bone graft is a surgical procedure to reconstruct bone after trauma, infection, or disease, improve bone healing response, and regenerate bone tissue around implanted devices [7-9]. The three main types of bone graft are autografts, allografts and xenografts. Autografts or autologous grafts are the gold standard in bone grafts as they contain both standards in bone grafts since it contains both osteogenic cells and an osteoconductive mineralized extracellular matrix where these can grow and proliferate. Autografts are harvested bone tissues from the same patient for transplanting to the place it is needed $[10,11]$. However, this type of graft's major drawback is a secondary surgical operation performed at the tissue harvest site that may result in complications such as donor side damage, defect, traumatize, and morbidity [10]. To overcome this problem, allografts being introduced. 
Allografts are bones from a donor of the same species for bone graft procedure. Allograft provides an alternative option for the treatment of complicated bony defects. However, allografts lead to other problems, including the risk of infections, an immune response of host tissue, disease transmission, and limited biological and mechanical properties $[12,13]$. Then, a bone donor from different species being introduced, known as xenograft. Cruciate ligament from porcine and dog tibia being used for bone grafting process. However, due to high immunity, insufficient biomechanical qualities, and foreign body reaction, this type of bone graft is abandoned as it creates a new problem rather than developing a new solution from limitations in autograft and allograft [7,14]. From all the disadvantages of autografts, allografts and xenografts, biomaterials are introduced to overcome that issue.

Biomaterials is a systemically and pharmacologically inert substance designed for implantation within or incorporation with living systems $[15,16]$. In simple terms, biomaterials are any material, natural or human-made, consisting of a whole or part of a living structure or biomedical device that performs, enhances, or replaces a natural function [17]. Calcium phosphate $(\mathrm{CaP})$ is one of the biomaterials that researchers eagerly develop due to its suitability to be used as a carrier for drugs, non-viral gene delivery, antigens, enzymes, and proteins $[18,19]$. Besides, CaP also an excellent material in bioactivity and biocompatibility [20]. Based on industry trends, the CaP market size value in 2018 was over USD 640 million and is expected to increase by over 5\% in 2025 [21,22]. From this trend, $\mathrm{CaP}$ is still relevant to be produced due to its market demand. Three types of $\mathrm{CaP}$ show high research interest. These are hydroxyapatite (HA), tricalcium phosphate (TCP), and biphasic calcium phosphate (BCP). In bone engineering application, calcium phosphate from HA, TCP, and BCP becomes a choice as it calcium to phosphorus $(\mathrm{Ca} / \mathrm{P})$ ratio in the range of bone $\mathrm{Ca} / \mathrm{P}$ ratio 1.37 to $1.87[23,24]$. To produce $\mathrm{CaP}$, calcium and phosphate precursor must be mixed together through the precipitation process with an additional $\mathrm{pH}$ adjuster to make sure the solution in the alkaline $\mathrm{pH}$ range. Calcium precursors in this research work from chicken eggshell waste converted to calcium oxide $(\mathrm{CaO})$. Eggshell waste contains a high percentage of calcium contains (94-97\%) in calcium carbonate $\left(\mathrm{CaCO}_{3}\right)$ or also known as calcite form [25,26]. To date, eggshells can serve as a promising biomaterials source because of their continuous resource compared to other natural sources of $\mathrm{CaP}$ like bovine bones and corals. Obtaining $\mathrm{CaO}$ is essential as it is a raw material for producing $\mathrm{CaP}$ that will be further synthesized through various synthesis methods such as precipitation, sol-gel, etc., in the manufacturing of scaffolds or any other biomedical needs [27-30].

This research work focused on the synthesis of $\mathrm{CaP}$ from chicken eggshells as the source of calcium precursor with phosphate precursor from ortho-phosphoric acid and additional ammonia solution that act as $\mathrm{pH}$ adjuster. The chemical, physical, and morphological properties of the materials were studied.

\section{Materials and Methods}

\subsection{Sample preparation.}

The collected eggshells were washed and immersed in boiling water for 30 minutes to remove any surface contaminants. Next, these eggshells were dried in the oven for 3 hours before crushed into smaller flakes using alumina mortar. Then, these eggshell flakes were calcined at a temperature of $900^{\circ} \mathrm{C}$ for 4 hours in the furnace for a complete transformation of $\mathrm{CaCO}_{3}$ into $\mathrm{CaO}$ powders to ensure complete carbon dioxide removal $\left(\mathrm{CO}_{2}\right)$ [31]. 


\subsection{Synthesis of $\mathrm{CaP}$.}

$\mathrm{CaP}$ powders were prepared by using the wet chemical precipitation method. $\mathrm{CaO}$ powders obtained were introduced into a beaker containing $250 \mathrm{ml}$ of distilled water and stirred for 30 minutes at a temperature of $60^{\circ} \mathrm{C}$. The powder was ultimately dissolved by warming the solution.

$$
\mathrm{CaO}+\mathrm{H}_{2} \mathrm{O}=\mathrm{Ca}(\mathrm{OH})_{2}
$$

Then, $14.7 \mathrm{ml}$ of ortho-phosphoric acid $\left(\mathrm{H}_{3} \mathrm{PO}_{4}\right)$ dissolved in $250 \mathrm{ml}$ of distilled water were added into the suspension and continue to be stirred until temperature up to $80^{\circ} \mathrm{C}$ producing white-colored precipitate. Next, ammonia solution $\left(\mathrm{NH}_{3}\right)$ was added as a $\mathrm{pH}$ adjustment until the suspension's $\mathrm{pH}$ reached 9-12. The reacted suspension, which was milky, was left resting (aging) in the fume cupboard for 24 hours before the precipitation product was filtered.

$$
3 \mathrm{Ca}(\mathrm{OH})_{2}+2 \mathrm{H}_{3} \mathrm{PO}_{4} \stackrel{\mathrm{NH}_{3}}{\longrightarrow} \mathrm{Ca} 3\left(\mathrm{PO}_{4}\right)_{2}+6 \mathrm{H}_{2} \mathrm{O}
$$

The solid white product collected from filtration was oven-dried at a temperature of $80^{\circ} \mathrm{C}$ for 2 hours. The product was then rinsed with distilled water and filtered again to dissolve any unreacted phosphate during the reaction process. Later, the product was oven-dried at a temperature of $100^{\circ} \mathrm{C}$ for 2 hours. The agglomerated white powder was crushed using a mortar and sieved until the size powder's average obtained was $\approx \leqq 60 \mu \mathrm{m}$. Lastly, the synthesized powder was calcined at various temperatures of $600,700,800,900$ and $1000^{\circ} \mathrm{C}$ for 3 hours at $5^{\circ} \mathrm{C} / \mathrm{min}$ of heating and cooling rates. The calcined powder was roughly crushed in a mortar and pestle to get the final refine powder.

\subsection{Characterization.}

\subsubsection{X-ray diffraction (XRD).}

The phase analysis of calcined powders was determined under XRD analysis. All the uncalcined and calcined powders were placed into the sample holder. This instrument works with voltage and the current setting of $30 \mathrm{kV}$ and $40 \mathrm{~mA}$, respectively, and uses $\mathrm{Cu}-\mathrm{K} \alpha$ radiation $(\lambda=0.15406 \mathrm{~nm})$. For qualitative analysis, XRD diagrams were recorded in $2 \theta=10^{\circ}$ $100^{\circ}$ at a step size of $0.02^{\circ}$, and the step time is $2 \mathrm{~s}$ per step. Then, the lattice parameters and atomic position were refined by using OriginPro 2018 and X'Pert HighScore software programs.

\subsubsection{Fourier transform-IR (FTIR).}

The functional group of synthesized calcium phosphate powders was obtained using an FTIR spectrometer. All powder samples must be finely ground to reduce scattering losses and absorption band distortions. Attenuated Total Reflection (ATR) powder technique was used with range 600 to $4000 \mathrm{~cm}^{-1}$; accommodation $32 \mathrm{scan}$ and resolution of $4 \mathrm{~cm}^{-1}$.

\subsubsection{Scanning electron microscopy (SEM).}

Morphological analysis of the powder samples was examined under SEM with high magnification, and EDX was performed to determine each sample's percentage composition. All samples were double-coated by gold using a sputter coater on the surface to create a conductive layer and reduce the samples' charging. 


\section{Results and Discussion}

\subsection{Characterization of $\mathrm{CaP}$.}

\subsubsection{X-ray diffraction (XRD) analysis.}

The identification of the crystalline phase of uncalcined and calcined $\mathrm{CaP}$ powders at a temperature range from 600 to $1000^{\circ} \mathrm{C}$ was conducted by $\mathrm{X}$-ray diffraction to confirm the phase existence. The diffraction patterns are shown in Figure 1.

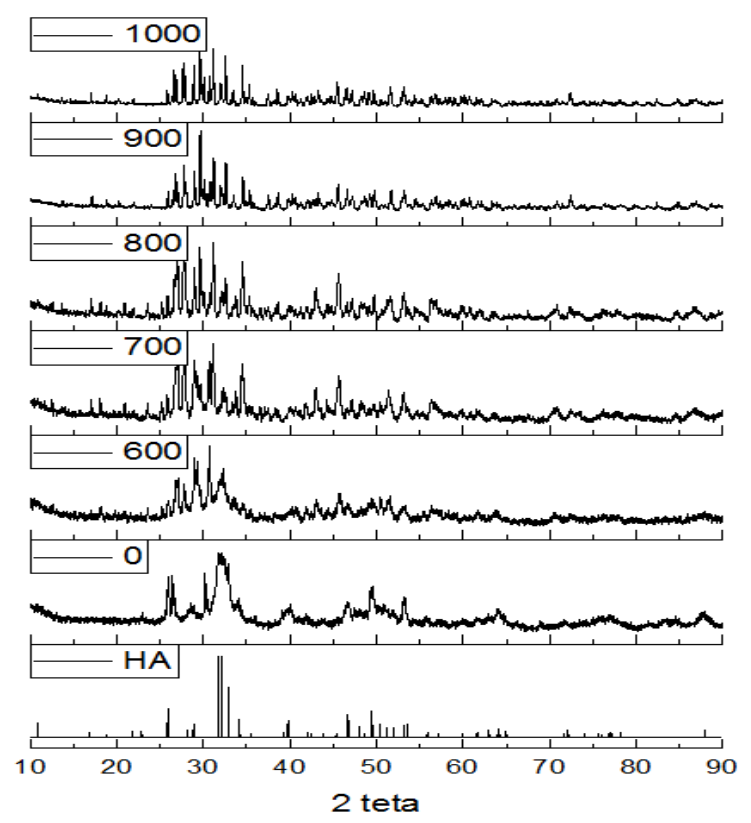

(a)

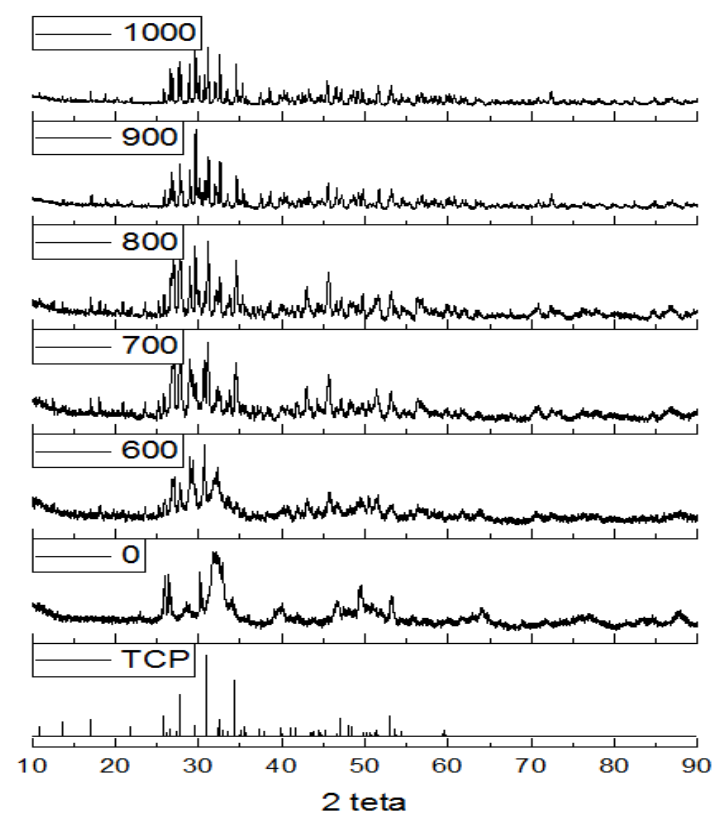

(b)

Figure 1. XRD pattern for a sample at different temperatures. (a) HA pattern; (b) TCP pattern.

The crystalline phase of HA powder confirmed the formation of an amorphous $\mathrm{CaP}$ precursor, as shown by significant peaks appear at (111), (002), (211), (112), (130), (213), (004), (323), (323), (210), (401), (313), (321) and (333) planes respectively in accordance to JCPDS file no. 74-0566. The characteristics of XRD patterns of hexagonal symmetry HA powder were identified at a temperature range from 0 to $700^{\circ} \mathrm{C}$. The sharp peaks are obtained at $2 \theta$ value of $26^{\circ}, 32^{\circ}, 46^{\circ}, 49^{\circ}, 57^{\circ}$, and $64^{\circ}$ indicates complete crystallization of the synthesized HA. Moreover, the broad peaks indicating low crystallinity of HA are obtained at $2 \theta$ values of $30^{\circ}-35^{\circ}, 49^{\circ}-53^{\circ}$, and $64^{\circ}$ as a result of impurity in synthesized HA powder. Besides, it is confirmed that there is no other crystalline phase, and there are no concurrences of secondary phases other than HA during HA formation. Furthermore, the HA's peaks were further reduced, indicating the gradual disappearance of HA and the appearance of $\beta$-TCP as a secondary phase. When heat-treated at $700^{\circ} \mathrm{C}$, these peaks biphasic can be discovered where at $2 \theta$ value of $25^{\circ}, 33^{\circ}$, and $46^{\circ}$ for HA whereas $\beta$-TCP peaks started to appears at $28^{\circ}, 32^{\circ}$, and $36^{\circ}$. The new peaks of $\beta$-TCP match the JCPDS file no. 70-2065 belongs to the rhombohedral symmetry. As the temperature increase from 700 to $1000^{\circ} \mathrm{C}$, the appearance of $\beta$-TCP peaks getting more distinct at (122), (211), (0210), (300) and (220) planes, respectively.

According to previous works, the sharper peaks of higher calcination temperature results indicate the higher crystallinity structure obtained. Besides, the formation of $\beta$-TCP may arise due to multiple variables during the synthesis process, such as chemical impurity, the concentration of aqueous solutions, processing $\mathrm{pH}$, including calcination temperature [32]. In 
addition, the profile of synthesized HA and $\beta$-TCP was in agreement with the profile of the commercial calcium phosphates. The reaction at $600^{\circ} \mathrm{C}$ showed the formation of HA with no other phase also at $700^{\circ} \mathrm{C}$, although there is a small quantity of $\beta$-TCP. At the temperature of $800^{\circ} \mathrm{C}$, the synthesized powder showed that $\beta$-TCP is easily formed at the beginning of higher heat treatment and remains the main phase until temperature reaches $1000^{\circ} \mathrm{C}$. Other related works found that the $\mathrm{HA}$ phase can stabilize up to $1300^{\circ} \mathrm{C}$ [33]. The duration of calcination, which is 3 hours, did not significantly affect the crystalline powder produced than calcination temperature, which plays a crucial role in this experiment. It implies that, heat treatment must be performed at a minimum temperature of $600^{\circ} \mathrm{C}$, as stated by previous works, to ensure complete removal of any organic substances and residue from the experiment's synthesized part [30]. Plus, higher calcination temperature can promote to more stable crystal with higher intensity of final products.

\subsubsection{Fourier transform-IR (FTIR) analysis.}

Fourier transform infrared (FTIR) spectrometry was analyzed to determine the functional group of both simultaneously uncalcined and calcined $\mathrm{CaP}$. Figure 2 shows the IR spectra of both uncalcined $\left(0^{\circ} \mathrm{C}\right)$ and calcined $\mathrm{CaP}$ from 600 to $1000^{\circ} \mathrm{C}$.

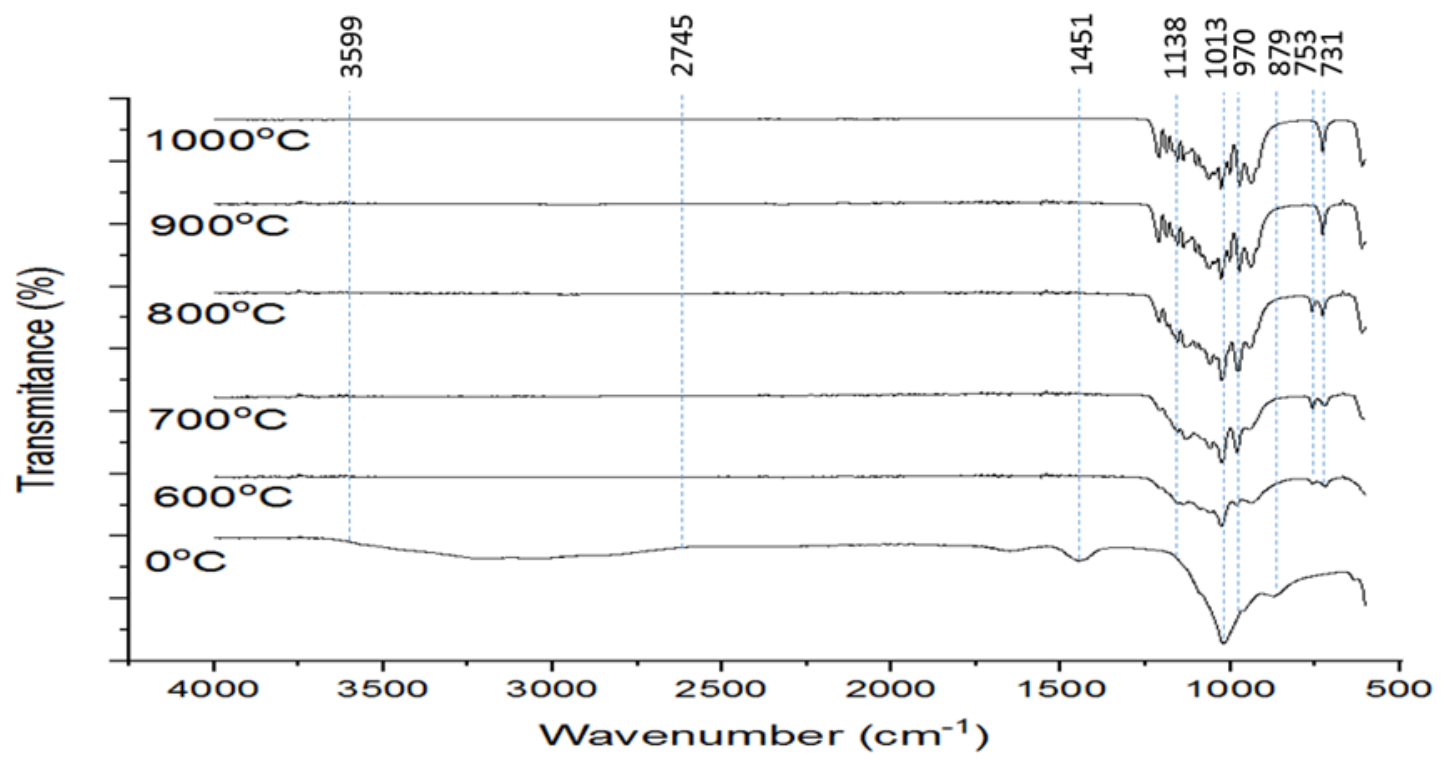

Figure 2. FTIR pattern of $\mathrm{CaP}$ powder at different temperatures.

Based on Figure 2, the FTIR pattern of uncalcined CaP shows broadband from 3599 to $2745 \mathrm{~cm}^{-1}$ indicates the presence of adsorbed water in the surface of the CaP particle due to moisture as the sample not being calcined [34,35]. From this broadband, it has been attributed as $\mathrm{H}$-bonded water of humidity [36]. After $\mathrm{CaP}$ being calcined, this band disappears as heat removes water from the sample. Carbonate ion, $\mathrm{CO}_{3}{ }^{-2}$, bands were spot for temperature $0^{\circ} \mathrm{C}$ at 1451 and $879 \mathrm{~cm}^{-1}$ where it can be ascribed to B-type carbonate substitution on phosphate ion sites [37]. The presence of signals from the carbonate vibrations is typical of natural phosphates and can be associated with the phosphate groups' substitution by the carbonate ones inside the crystals [38]. Type B apatite has better bioactivity and is better for bone replacement due to its similarity to biological apatites in human bone [39]. For samples at temperatures 600 to $1000^{\circ} \mathrm{C}, \mathrm{CO}_{3}{ }^{-2}$ band does not appear. $\mathrm{CO}_{3}{ }^{-2}$ is caused by an atmosphere-opened reaction that allows $\mathrm{CO}_{2}$ incorporation into the particle's surface. After calcination, it is possible to observe a decrease in these bands' intensity because adsorbed groups tend to be eliminated at high 
temperatures [34]. For phosphate ion $\mathrm{PO}_{4}^{-3}$ band, 1138 and $1013 \mathrm{~cm}^{-1}$ shows $v 3$ antisymmetric stretching while $970 \mathrm{~cm}^{-1}$ shows $v_{1}$ symmetric stretching [40,41]. $v_{2}$ symmetric bending and $v_{4}$ antisymmetric bending cannot be detected as the scanning range of this sample is 600 to 4000 $\mathrm{cm}^{-1}$ while $v_{2}$ and $v_{4}$ state around 599 to $460 \mathrm{~cm}^{-1}$. However, the characteristic band position for the CaP band position can still be detected at 1138, 1013, and $970 \mathrm{~cm}^{-1}$, which shows all this sample is in $\mathrm{CaP}$ form [38]. The band at $753 \mathrm{~cm}^{-1}$ indicates $\alpha$-pyrophosphate, $\alpha-\mathrm{P}_{2} \mathrm{O}_{7}^{-4}$ and when $\mathrm{CaP}$ being calcined to a temperature above $900^{\circ} \mathrm{C}$ this band disappears. The band at 731 $\mathrm{cm}^{-1}$ shows $\mathrm{P}_{2} \mathrm{O}_{7}^{-4}$ ion, where the intensity of this peak increase with the increasing calcination temperature. This peak becomes sharper by calcined the sample, which agrees with converting hydrogen phosphate ion, $\mathrm{HPO}_{4}{ }^{-2}$ to $\beta$-TCP after calcination at 600 to $1000^{\circ} \mathrm{C}[42,43]$.

\subsubsection{Scanning electron microscopy (SEM) analysis.}

The morphological analyses of $\mathrm{CaP}$ powders were shown in Figure 3, which reveals the favorable outcome in the synthesis of $\mathrm{CaP}$ particles with an average $60 \mu \mathrm{m}$ particle size in this experimental work. Morphology samples that did not experience heat treatment (Figure 3a) reveal petals and needle-like shapes for the most part. It also tends to become a more fibrous cluster due to poor crystallization due to low calcination temperature.
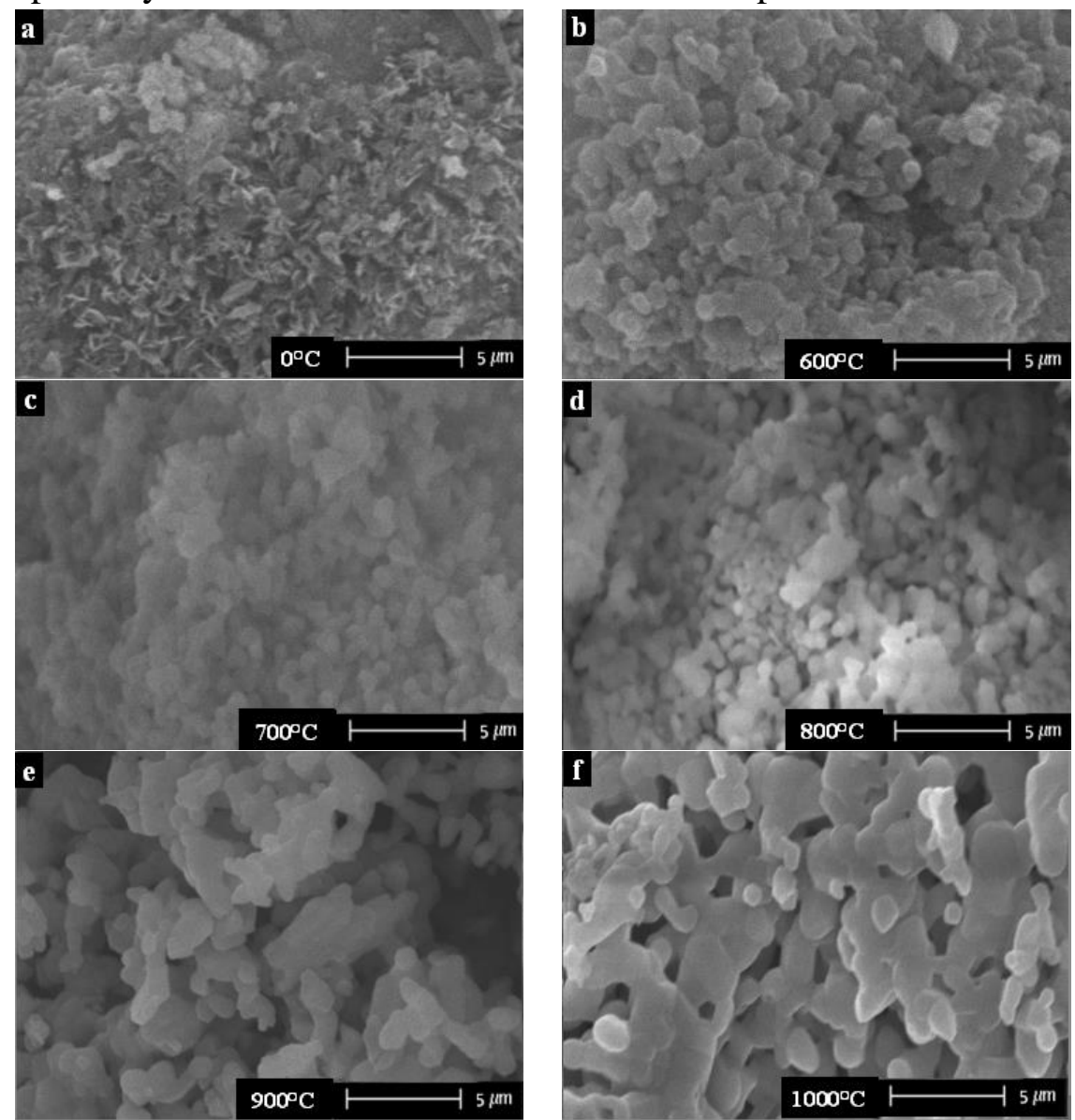

Figure 3. SEM image for $\mathrm{CaP}$ after calcined at different temperature: (a) $0^{\circ} \mathrm{C} ;(\mathbf{b}) 600^{\circ} \mathrm{C} ;$ (c) $700^{\circ} \mathrm{C} ;(\mathbf{d}) 800^{\circ} \mathrm{C}$; (e) $900^{\circ} \mathrm{C} ;(\mathbf{f}) 1000^{\circ} \mathrm{C}$.

Moving on to a temperature range of $600^{\circ} \mathrm{C}$ to $800^{\circ} \mathrm{C}$ (Figure $3 \mathrm{~b}, \mathrm{c}, \mathrm{d}$ ) showed the samples transform to more fluffy and rounded-edge, which is a typical morphological pattern for calcium phosphate powder that contains HA. Other related works also justify this pattern as a rice-like pattern that is formed by many agglomerations [27]. This emphasizes that morphology transformation is mainly due to the effect of high calcination temperature. As 
mentioned, temperature affects crystal growth because of molecules' faster movement, resulting in them evaporating rapidly. Figure $3 \mathrm{e}$ responds to expectation where the agglomeration samples display irregular, more connected shapes starting to welded together. Pointed to the fact that at $1000^{\circ} \mathrm{C}$, starting the formation of inter-particle necks and will grow along with the increase in temperature up to $1200^{\circ} \mathrm{C}$, and the pore is starting to shrink [44].

Table 1. EDX analysis for $\mathrm{CaP}$ powder at different calcination temperatures.

\begin{tabular}{|c|c|c|c|c|}
\hline Sample & Element & Atomic\% & Weight \% & $\mathrm{Ca} / \mathrm{P}$ \\
\hline \multirow{2}{*}{$0^{\circ} \mathrm{C}$} & $\mathrm{Ca}$ & 61.96 & 67.83 & \multirow{2}{*}{1.63} \\
\hline & $\mathrm{P}$ & 38.04 & 32.17 & \\
\hline \multirow{2}{*}{$600^{\circ} \mathrm{C}$} & $\mathrm{Ca}$ & 60.58 & 66.53 & \multirow{2}{*}{1.54} \\
\hline & $\mathrm{P}$ & 39.42 & 33.47 & \\
\hline \multirow{2}{*}{$700^{\circ} \mathrm{C}$} & $\mathrm{Ca}$ & 59.70 & 65.72 & \multirow{2}{*}{1.48} \\
\hline & $\mathrm{P}$ & 40.30 & 34.28 & \\
\hline \multirow{2}{*}{$800^{\circ} \mathrm{C}$} & $\mathrm{Ca}$ & 57.14 & 63.42 & \multirow{2}{*}{1.36} \\
\hline & $\mathrm{P}$ & 42.86 & 36.58 & \\
\hline \multirow{2}{*}{$900^{\circ} \mathrm{C}$} & $\mathrm{Ca}$ & 54.79 & 61.07 & \multirow{2}{*}{1.21} \\
\hline & $\mathrm{P}$ & 45.21 & 38.93 & \\
\hline \multirow{2}{*}{$1000^{\circ} \mathrm{C}$} & $\mathrm{Ca}$ & 53.77 & 60.08 & \multirow{2}{*}{1.16} \\
\hline & $\mathrm{P}$ & 46.23 & 39.92 & \\
\hline
\end{tabular}

EDX analysis in Table 1 confirms the purity of the materials being composed solely of $\mathrm{Ca}$ and $\mathrm{P}$ and $\mathrm{O}$ and $\mathrm{H}$. Even though the EDX analysis is qualitative. It can help identify the calcium and phosphorous ratio from the atomic percentage (atom \%) [45]. The results of $\mathrm{Ca} / \mathrm{P}$ ratio were calculated for all samples obtained, mainly calcium-deficient $\mathrm{HA}$ in which comparable to $\mathrm{CaP}$ found in bone and teeth. $\mathrm{CaP}$ with $\mathrm{Ca} / \mathrm{P}$ ratio that is less than 1.5 would be likely less stable. This is because the higher $\mathrm{Ca}$ deficiency that leads to the imperfection of the structure [46]. The samples at temperature 600 and $1000^{\circ} \mathrm{C}$ display a $\mathrm{Ca} / \mathrm{P}$ ratio $<1.5$, leading to the formation of $\beta$-TCP in which proved in XRD analysis where $\beta$-TCP starting to appear at $700^{\circ} \mathrm{C}$. The presence of $\beta$-TCP in calcium phosphates powder can be benefited for its good solubility and degradation rate, which it can be chosen as starting materials for bioresorbable graft.

\section{Conclusions}

Calcium phosphate $(\mathrm{CaP})$ is successfully synthesized through the precipitation process using eggshell waste treated with calcium oxide $(\mathrm{CaO})$ as calcium precursor and orthophosphoric acid as phosphate precursor with additional ammonia solution that acts as $\mathrm{pH}$ adjuster. For XRD analysis, two types of $\mathrm{CaP}$ can be detected: hydroxyapatite (HA) and $\beta$ Tricalcium phosphate ( $\beta$-TCP). FTIR analysis shows $\mathrm{H}-$ band, $\mathrm{CO}_{3}{ }^{-2}, \mathrm{PO}_{4}^{-3}, \mathrm{P}_{2} \mathrm{O}_{7}{ }^{-4}$ that occur due to different samples' calcination temperatures. SEM shows a needle-like shape for uncalcined $\mathrm{CaP}$ to more fluffy and rounded-edge for $\mathrm{CaP}$ calcined at 600 to $800^{\circ} \mathrm{C}$, an irregular, more connected shape starting to weld together for sample $900^{\circ} \mathrm{C}$ and transform to interparticle necks for $1000^{\circ} \mathrm{C}$. Ca to $\mathrm{P}$ ratio $(\mathrm{Ca} / \mathrm{P})$ resulted in a 1.16 to $1.63 \mathrm{Ca} / \mathrm{P}$ ratio. The synthesized $\mathrm{CaP}$ powder with calcined $\mathrm{CaP}$ powder at 600 to $700^{\circ} \mathrm{C}$ suitable for biomedical implant in hard tissue engineering application based on its $\mathrm{Ca} / \mathrm{P}$ ratio.

\section{Funding}

This research was funded by Post-Graduate Research Grant (GPPS), grant number H540 and Fundamental Research Grant Scheme (FRGS), grant number K199. 


\section{Acknowledgments}

The authors wish to acknowledge their appreciation to the Faculty of Mechanical and Manufacturing Engineering (FKMP), Universiti Tun Hussein Onn Malaysia (UTHM), for the use of the facilities.

\section{Conflicts of Interest}

The authors declare no conflict of interest.

\section{References}

1. Lim, J.; You, M.; Li, J.; Li, Z. Emerging bone tissue engineering via polyhydroxyalkanoate (PHA) - Based scaffolds. Mater. Sci. Eng. C 2017, 79, 917-929, https://doi.org/10.1016/j.msec.2017.05.132.

2. Cao, G.; Huang, Y.; Li, K.; Fan, Y.; Xie, H.Q.; Li, X. Small intestinal submucosa: superiority, limitations and solutions, and potential to address bottlenecks in tissue repair. J Mater Chem B 2019, 7, 5038-5055, https://doi.org/10.1039/C9TB00530G.

3. Setiawati, R.; Rahardjo, P. Bone development and growth. In Osteogenesis and Bone Regeneration, 1st ed.; Yang, H., Eds.; IntechOpen: London, United Kingdom, 2019; 1, 1-20, https://doi:10.5772/intechopen.739554.

4. Von Euw, S.; Wang, Y.; Laurent, G.; Drouet, C.; Babonneau, F.; Nassif, N.; Azais, T. Bone mineral: New insights into its chemical composition. Sci. Rep 2019, 9, 1-11, https://doi.org/10.1038/s41598-019-44620-6.

5. Gasser, J.A.; Kneissel, M. Bone physiology and biology. In Bone Toxicology, 1st ed.; Smith, S.Y.; Varela, A.; Samadfam, R., Eds.; Springer: Cham, Switzerland, 2017; 1, 27-94, https://doi.org/10.1007/978-3-31956192-9.

6. Adzila, S.; Mustaffa, N.A.; Kanasan, N. Magnesium-doped calcium phosphate/sodium alginate biocomposite for bone implant application. J Aus Ceram Soc. 2020, 56, 109-115, https://doi.org/10.1007/s41779-01900417-4.

7. Dinçel, Y.M. Bone graft types. In Bone Grafting: Recent Advances with Special References to CranioMaxillofacial Surgery, 1st ed.; Kummoona R., Eds.; IntechOpen: London, United Kingdom, 2018, 1, 27-40, http://dx.doi.org/10.5772/intechopen.73956

8. Fillingham, Y.; Jacobs, J. Bone grafts and their substitutes. Bone Jt. J. 2016, 98, 6-9. https://doi.org/10.1302/0301-620X.98B.36350.

9. Li, R.; Zhu, G.; Chen, C.; Chen, Y.; Ren, G. Bone transport for treatment of traumatic composite tibial bone and soft tissue defects: any specific needs besides the Ilizarov Technique?. BioMed Res. Int. 2020, 2020, $1-$ 13, https://doi.org/10.1155/2020/2716547.

10. Haugen, H.J.; Lyngstadaas, S.P.; Rossi, F.; Perale, G. Bone grafts: Which is the ideal biomaterial? J. Clin. Periodontol. 2019, 46, 92-102, https://doi.org/10.1111/jcpe.13058.

11. Baldwin, P.; Li, D.J.; Auston, D.A.; Mir, H.S.; Yoon, R.S.; Koval, K.J. Autograft, allograft, and bone graft substitutes: Clinical evidence and indications for use in the setting of orthopaedic trauma surgery. J. Orthop. Trauma 2019, 33, 203-213, https://doi.org/10.1097/BOT.0000000000001420.

12. Moore, M.A.; Samsell, B.; McLean, J. Allograft tissue safety and technology. In Biologics in Orthopaedic Surgery, 1st ed.; Wolfe, K.; Horigan, J., Eds.; Elsevier: Missouri, United States, 2019; 1, 49-62, https://doi.org/10.1016/B978-0-323-55140-3.00005-9.

13. Singh, H.; Moss, I.L. Chapter 15 - Biologics in spinal fusion. In Biologics in Orthopaedic Surgery, 1st ed., Mazzocca, A.D.; Lindsay, A.D., Eds.; Elsevier: Missouri, United States, 2019; 1, 165-174, https://doi.org/10.1016/B978-0-323-55140-3.00015-1.

14. Mahyudin, F.; Utomo, D.N.; Suroto, H.; Martanto, T.W.; Edward, M.; Gaol, I.L. Comparative effectiveness of bone grafting using xenograft freeze-dried cortical bovine, allograft freeze-dried cortical New Zealand white rabbit, xenograft hydroxyapatite bovine, and xenograft demineralized bone matrix bovine in bone defect of femoral diaphysis of white rabbit: Experimental study in vivo. Int. J. Biomater 2017, 2017, 1-9. https://doi.org/10.1155/2017/7571523.

15. Marin, E.; Boschetto, F.; Pezzotti, G. Biomaterials and biocompatibility: An historical overview. J. Biomed. Mater. Res. A 2020, 108, 1617-1633, https://doi.org/10.1002/jbm.a.36930. 
16. Rezaie, H.R.; Rizi, H.B.; Khamseh, M.M.R.; Öchsner, A. Primary information about biomaterials. In A Review on Dental Materials, 1st ed., Rezaie, H.R.; Rizi, H.B.; Khamseh, M.M.R.; Öchsner, A., Eds.; Springer: Cham, Switzerland, 2020; 1, 1-30, https://doi.org/10.1007/978-3-030-48931-1_1.

17. Khan, M.Y.; Chen, M.H. A review on role of biomaterials in biomedical field. IJBPR 2019, 8, 2788-2793, https://doi.org/10.21746/ijbpr.2019.8.9.2.

18. Prokopowicz, M.; Szewczyk, A.; Skwira, A.; Sądej, R.; Walker, G. Biphasic composite of calcium phosphatebased mesoporous silica as a novel bone drug delivery system. Drug Deliv. Transl. Res. 2020, 10, 455-470, https://doi.org/10.1007/s13346-019-00686-3.

19. Levingstone, T.J.; Herbaj, S.; Dunne, N.J. Calcium phosphate nanoparticles for therapeutic applications in bone regeneration. Nanomaterials 2019, 9, 1570-1592, https://doi.org/10.3390/nano9111570.

20. Adzila, S.; Mustaffa, N.A.; Kanasan, N.; Nordin, N.; Rus, A.Z.M.; Bano, N. Effect of sodium alginate on the properties of calcium phosphate for bone implant application. Int. J. Nanoelectron. Mater 2020, 13, 1-9. https://ijneam.unimap.edu.my/images/PDF/InPress\%20Special\%20Issue\%202020/Paper\%20ID\%204.pdf

21. Calcium Phosphate Market Outlook. Available online: https://www.gminsights.com/industryanalysis/calcium-phosphate-market (accessed on 13 September 2020).

22. Calcium Phosphate Market 2019 to 2025: Global Industry Size, Share, Growth, Trends and Forecast. Available online: https://www.gminsights.com/industry-analysis/calcium-phosphate-market (accessed on 13 September 2020).

23. Sierra, L.A.Q.; Escobar, D.M. Characterization and bioactivity behavior of sol-gel derived bioactive vitroceramic from non-conventional precursors. BOL SOC ESP CERAM V 2019, 58, 85-92. https://doi.org/10.1016/j.bsecv.2018.07.003.

24. Campion, C.; Hing, K.A. Porous bone graft substitutes.In Mechanobiology Exploitation for Medical Benefit, 1st ed., Rawlinson, S.C., Eds., John Wiley \& Sons: New Jersy, United Kingdom, 2017; 1, 347-371, https://doi.org/10.1002/9781118966174.ch21.

25. Owuamanam, S.; Cree, D. Progress of bio-calcium carbonate waste eggshell and seashell fillers in polymer composites: A review. J. Compo. Sci. 2020, 4, 70-92, https://doi.org/10.3390/jcs4020070.

26. Ajayan, N.; Shahanamol, K.P.; Arun, A.U.; Soman S. Quantitative variation in calcium carbonate content in shell of different chicken and duck varieties. Advances in zoology and botany 2020, 8, 1-5, https://doi.org/10.13189/azb.2020.080101.

27. Horta, M.; Aguilar, M.; Moura, F.; Campos, J.; Ramos, V.; Quizunda, A. Synthesis and characterization of green nanohydroxyapatite from hen eggshell by precipitation method. Mater. Today 2020, 14, 716-721. https://doi.org/10.1016/j.matpr.2019.02.011.

28. Hassanajili, S.; Pour, A.K.; Oryan A.; Khozani. T.T. Preparation and characterization of PLA/PCL/PHA composite scaffolds using indirect 3D printing for bone tissue engineering. Mater. Sci. Eng. C. 2019, 104, 113, https://doi.org/10.1016/j.msec.2019.109960.

29. Oladele, I.O.; Agbabiaka, O.G.; Adediran, A.A.; Akinwekomi, A.D.; Balogun, A.O. Structural performance of poultry eggshell derived hydroxyapatite based high density polyethylene bio-composites. Heliyon 2019, 5 , 1-7. https://doi.org/10.1016/j.heliyon.2019.e02552.

30. Zaman, T.; Mostari, M.; Mahmood, M.A.A.; Rahman, M.S. Evolution and characterization of eggshell as a potential candidate of raw material. Cerâmica 2018, 64, 236-241, https://doi.org/10.1590/036669132018643702349.

31. Najah, M. I.; Razak, A.; Nekmat, N.A.C.S.; Adzila, S.; Othman, R.; Nordin, N. Characterization of calcium carbonate extracted from eggshell waste at various calcination temperature. IJETER 2020, 8, 6725-6731, https://doi.org/10.30534/ijeter/2020/168102020.

32. Pankaew, P.; Hoonnivath, E.; Limsuwan, P.; Naemchanth, K. Temperature effect on calcium phosphate synthesized from chicken eggshells and ammonium phosphate. J. Appl. Sci. 2010, 10, 3337-3342. https://doi.org/10.3923/jas.2010.3337.3342.

33. Ho, W.F.; Hsu, H.C.; Hsu, S.K.; Hung, C.W.; Wu, S.C. Calcium phosphate bioceramics synthesized from eggshell powders through solid state reaction. Ceram. Int. 2013, 39, 6467-6473. http://dx.doi.org/10.1016/j.ceramint.2013.01.076.

34. Caliman, L.B.; Silva, S.N.D.; Junkes, J.A.; Sagrillo, V.P.D. Ostrich eggshell as an alternative source of calcium ions for biomaterials synthesis. Mater. Res. 2017, 20, 413-417, https://doi.org/10.1590/1980-5373mr-2016-0368. 
35. Anjaneyulu, U.; Sasikumar, S. Bioactive nanocrystalline wollastonite synthesized by sol-gel combustion method by using eggshell waste as calcium source. Bull. Mater. Sci. 2014, 37, $207-212$. https://doi.org/10.1007/s12034-014-0646-5.

36. Marques Correia, L.; Cecilia, J.A.; Rodríguez-Castellón, E.; Cavalcante, C.L.; Vieira, R.S. Relevance of the physicochemical properties of calcined quail eggshell $(\mathrm{CaO})$ as a catalyst for biodiesel production. J. Chem. 2017, 2017, 1-12, https://doi.org/10.1155/2017/5679512.

37. Wu, S.C.; Hsu, H.C.; Hsu, S.K.; Chang, Y.C.; Ho, W.F. Synthesis of hydroxyapatite from eggshell powders through ball milling and heat treatment. J. Asian Ceram. Soc. 2016, 4, 85-90, https://doi.org/10.1016/j.jascer.2015.12.002.

38. Kalbarczyk, M.; Szcześ, A.; Sternik, D. The preparation of calcium phosphate adsorbent from natural calcium resource and its application for copper ion removal. Environ. Sci. Pollut. Res. 2021, 28, 1725-1733, https://doi.org/10.1007/s11356-020-10585-7.

39. Hamidi, A.A.; Salimi, M.N.; Yusoff, A.H.M. Synthesis and characterization of eggshell-derived hydroxyapatite via mechanochemical method: A comparative study. AIP Conf. Proc. 2017, 1835, 1-13, https://doi.org/10.1063/1.4981867.

40. Rau, J.V.; Wu, V.M.; Graziani, V.; Fadeeva, I.V.; Fomin, A.S.; Fosca, M.; Uskoković, V. The Bone Building Blues: Self-hardening copper-doped calcium phosphate cement and its in vitro assessment against mammalian cells and bacteria. Mater. Sci. Eng. C. 2017, 79, 270-279, http://dx.doi.org/10.1016/j.msec.2017.05.052.

41. Corrêa, T.H.A.; Holanda, J.N.F. Calcium pyrophosphate powder derived from avian eggshell waste. Cerâmica 2016, 62, 278-280, http://dx.doi.org/10.1590/0366-69132016623631986.

42. Shavandi, A.A.; Bekhit, A.E.D.; Ali, A.; Sun, Z.; Ratnayake, J.T. Microwave-assisted synthesis of high purity $\beta$-tricalcium phosphate crystalline powder from the waste of Green mussel shells (Perna canaliculus). Powder Technol. 2015, 273, 33-39. https://doi.org/doi:10.1016/j.powtec.2014.12.029.

43. Salimi, E.;Javadpour, J. Synthesis and characterization of nanoporous monetite which can be applicable for drug carrier. J. Nanomater. 2012, 2012, 1-5, https://doi.org/doi:10.1155/2012/931492.

44. Ruiz-Aguilar, C.; Olivares-Pinto, U.; Aguilar-Reyes, E.A.; Lopez-Juarez, R.; Alfonso, I. Characterization of tricalcium phosphate powders synthesized by sol-gel and mechanosynthesis. BOL SOC ESP CERAM V 2018, 57, 213-220, https://doi.org/10.1016/j.bsecv.2018.04.004.

45. Opis, H.; Dinu, C.; Baciut, M.; Baciut, G.; Mitre, I.; Crisan, B.; Armencea, G.; Prodan, D.A.; Bran, S. Review: The influence of eggshell on bone regeneration in preclinical in vivo studies. Biology 2020, 9, 1-17, https://doi.org/10.3390/biology9120476.

46. Rahim, T.A.; Misran, F.; Mustafa, Z.; Shamsudin, Z. Eggshell derived calcium phosphate and its conversion $\begin{array}{lllll}\text { to dense } & \text { bodies. } & \text { 2020, } & \text { 65 } & \text { 334-341, }\end{array}$ http://www.akademiabaru.com/doc/ARFMTSV65_N2_P334_341.pdf. 